\title{
LEGACY OF EUROPEAN ENTERPRISE: TEACHING BUSINESS HISTORY IN THE INTERNATIONAL MANAGEMENT CURRICULUM
}

\author{
Marco Althaus
}

\section{Abstract}

Business history can be a valuable, even critical element in teaching international management - not only at elite institutions and at postgraduate level, but at universities of applied sciences and in undergraduate education, too. It is specifically relevant for programs with a focus on Europe. Students should be given a chance to discover common and connected pasts of European enterprise. The article offers a rationale for curriculum integration and discusses case selections and teaching methods for non-historians. Five exemplary themes are presented: East India companies, financial market bubbles, telegraphy, the Suez Canal, and the emergence of airlines.

\section{Zusammenfassung}

Unternehmensgeschichte kann ein wertvoller, sogar kritischer Beitrag in der Vermittlung des internationalen Managements sein - nicht nur an elitären Einrichtungen und im Master, sondern auch an Fachhochschulen und in Bachelor-Studiengängen. Besonders relevant ist sie für Studiengänge mit Fokus Europa. Studenten sollten eine Chance erhalten, die gemeinsame und zusammenhängende Vergangenheit europäischer Unternehmenstätigkeit zu entdecken. Der Artikel begründet die Integration ins Curriculum und diskutiert Fallauswahl und Lehrmethodik für Nichthistoriker. Eine exemplarische Auswahl von fünf Themen wird gezeigt: Ostindienkompanien, FinanzmarktBlasen, Telegrafie, der Suezkanal und die Entstehung von Fluggesellschaften.

\section{INTRODUCTION}

In fall 2013, five years after the 2008 financial panic, media and academic events were awash with retrospective: How could it happen? Can it happen again? What lessons have been learnt? The global economy, much less the Eurozone, is not yet back to normal. Even though some nations prosper, all continue to struggle. Economists are still searching for their soul; they received much blame for modeling the fantasy of efficient, well-tuned markets. Universities, too, were rebuked. They had trained the people who ran the casino, or trusted, sold and bought its promises. Business educators have reasons for critical self-inspection. Have they responded well enough?

Back then, students were deeply disturbed as anyone when the crisis hit. They demanded answers. Professors tried to explain; confused themselves, they tried to reconstruct events and put them in perspective. Most of those students are on the job market by now. A new generation is coming.
A first-semester student today was a fresh-faced teen when Lehman Brothers collapsed and when Eurozone leaders met to rescue whole nations. Chances are she did not pay much attention, nor did she understand. For her it is already history. Five years is a long time in a young person's life. She may or may not ask to discuss the recent past in class. Hopefully, she will. But what will professors tell her about the lessons of history? And what is their goal?

\section{FINDING A PLACE FOR HISTORY}

Among the post-2008 wake-up calls was the plea to engage future decisionmakers with history so they will not create crises just to relearn old lessons. It clicked with the new public audiences that business and economic historians found. Pedagogues like Mittelstaedt et al. (2013) argue that financial crises are "ideal teaching moments" due to their "great potential to encourage learning from the past and to foster socio-economic education" and help to "learn learning" (pp. 11, 19).
Yet universities did not make stringent efforts to secure history good spots in curricula. Understandably, business departments find it hard to squeeze in socially demanded extras, be they history, ethics, corporate citizenship or sustainability. Rather, faculties are pressed to purge overloaded curricula of ballast. Also, most European faculties maintain a core subject concept and lack the humanities and social science base of U.S. liberal arts colleges. A few take pride in a studium generale, but they are rare.

A killer argument is that young people do not enroll in business studies for antiquarian retro subjects. It is assumed that history is for them at best charming, at worst boring, but in any case wasteful and irrelevant to a career. They demand what universities advertise: newest management knowhow. Busy with the here and now and near future, they come not to be enlightened but to acquire skills and technical prowess which (they think) will impress employers. 
The attitude is advanced by the Bologna-induced priority on skills, competences and employability. Keen subscribers are institutions of vocational higher education: the degreegranting polytechnic, university of applied sciences, Fachhochschule in Germanic countries, Dutch hogeschool, Nordic högskola, and the like. Business studies are popular and growing there. Such schools promise to academically teach tools and techniques but use theory in lighter doses. That is a unique selling proposition. It forms the "applied" brand. Unsurprisingly, their management studies integrate only miniature curricula of economics; very few offer freestanding economics degrees. Most business historians drop anchor at large economics departments, so the "applied" school is no natural home.

Elite business schools may run a different kind of ship. Their clientele may expect a distinguished leadership education which offers the idea that if you want to make business history, you should also read it. It can be a cultural identifier, mark of habitus, or a copy of top American MBA schools where business history has a lobby and a tradition. More pedestrian universities have a less elite profile of students who "might not feel the need to understand how and why those who ruled the business world at some historical points did what they did" (Bucheli, 2012, p. 17).

There is one field where business education even at very down-to-earth universities is open to very broad interdisciplinary missions: international business (IB). Narrow functional-technical classes do not suffice. Employers want staff who can work in (and lead) cross-cultural teams, or as expatriates in irritatingly different environments. IB students are set to avoid traps of thinking "what works here works anywhere." They try to make sense of varieties in organization, employment standards, or finance traditions. They are aware of nuances as they practice intercultural communication. They study Hofstede's cultural dimensions.
They work on languages, country and regional studies. They learn to decipher foreign institutions, laws, norms, geography, whole economic systems. Naturally, without a clue of how history shaped them, the IB student will be all at sea.

Strangely, history slips into IB programs by stealth. The camouflage is "culture." IB programs are unthinkable without cultural classes, and deep down in module descriptions they happily sink history. But IB departments avoid course titles which have the word history in it. It is a symptom of presentism: culture is alright since it is a factor in the present; but history is dead past. History finds acceptance as an auxiliary to grasp culture, which in turn is auxiliary to core management classes.

There is a serious issue hidden under the camouflage. History is put to classes on cultural, social, and political environments of business. All fine, but where is the dedicated history of business, companies and management, rather than the history of cultures, societies, and politics?

Such history can aid IB students attain the "gift of professional maturity" which comes to those who know their discipline's history (Bedeian, 2004). Modern subjects often confuse students with complexity. They may find reassurance in the fact that managers long ago struggled with fairly the same complex problems. Understanding their struggles, their half-baked successes or failures can support asking better questions. Students can learn that to consult history is an extra tool in their toolbox. It helps build a critical mind vis-à-vis change, continuity, and practices hyped as "new". It makes aware that business trends are outcomes of their own times and places. Business history yields judgment skills, transferable and complementary to many IB subfields.

This is not to suggest that the benchmark is the standalone business history course. It would be great if depart- ments followed the Copenhagen Business School, where an IB flagship English-taught B.Sc. starts off with a mandatory class, "The Company in its Historical and International Setting." Realistically, few IB departments will copy that. Some pursue electives, studium generale subjects, or non-credit lectures. However, the author would propose that business history can be part of core IB classes. Granted, one has to make room, i.e. scrap other valuable topics. But a link-up of history with newest content offers creative chances and deepens the modern knowledge universities wish to confer.

It reflects the author's experience teaching an "International Management in Europe" course (five credit points, four semester weekly hours), a capstone for Wildau's B.A. in European Management (EM). It is an IB degree in European clothes, with a long track of "European Competences" classes on EU institutions, laws and policies, culture and languages. The consecutive M.A. has more EU modules and a twosemester track "European Identities" in four tongues. The degree is an applied business alternative to generalist European studies at many universities. Its mission is, notably, not to train the next generation of EU praetorian guards; it is no boot camp for Captain Europe waving a blue gold-starred flag. The EM program's goal is to make graduates who are adept in Europe's everyday business affairs. But the degree should attract natural Europhiles. They should graduate with a distinct identity as "European Managers" (with a capital M), showing expert pride. Per contra, the author's consistent experience has been that they rather do not.

In fact, many students even refute the degree's claim that its European profile earns them job-marketable IB expertise. They yearn for "specialization" but do not see it in the European aspect of IB. Also, the most ambitious seek, in growing numbers, internships or a semester out not with Erasmus but in destinations like Brazil and China. Not because those are more exotic than

${ }^{1}$ In Germany, Hochschule Osnabrück (2011) won attention when it opened a B.A. in "Applied Economics." Seen as a radical departure, the program was presented as a "reaction to the financial crisis," an effort to "educate socially responsible economists" and be "closer to reality" (than traditional research universities). It starts with an economic history class and adds behavioral economics and ethics, all compulsory. 
Tallinn, Rotterdam, Porto, Sofia or Limerick but promise more dazzling CV credentials. "That's where the music plays," some say. It would be silly to criticize their global appetite. The author's university proudly promotes its partnerships with non-European places. But EM students' non-identity as "European Managers" is a strange outcome of the EM curriculum. Somehow a piece of identity seems to be missing.

EM teaching staff have scratched their heads over students' distance to the core EM profile. The scratch point transfers to other university programs educating for the Single Market. What, if not commitment to Europe, sets them apart from IB degrees anywhere? Identity is a complex matter, even more so when talk is of European identity. That is the subject of a prolific literature. It is ambiguous, vague, some say artificial. Still, formal education has socializing effects which may frame a European identity as a serious attitude "based not on spontaneous affinities but on reflection;" admittedly success is limited since identity is formed on the streets, too (Banús, 2007, S. 58).

The author would stipulate that if his department has failed at one crucial point, it is this: The EM program has no manifest idea for a "European Manager" as a persona or self-concept which connects a unique career definition with personal identification with Europe. The department has also not tackled the question if the "European Manager" view may change with the EU's crisis, which is an identity crisis as much as an economic one. Few EM students are idealists, enthusiasts, or just optimists about Europe. Many lack confidence that its economy is a reliable engine; they repeat media messages that Europe equals stagnation. Like most young people, they do not enjoy the potboilers of the peace project and the "ever closer union" with the largest market on earth, the Euro its shiny crown. The crisis has exposed, in harshly negative ways, the divergence of the 28 (EU) or 50 (Europe) nations, rather than what Europe holds in common in experience and legacy.

One missing piece in the identity puzzle may be a lack of explicit effort to represent European business roots. History, not seen as pure chronicle ("one damn thing after another"), forges understanding self and others. It provides a sense of affiliation and continuity through a narrative reservoir about who we are, where we came from and where we are going. Business history opens eyes for nuances, dilemmas, solutions, and opportunities in enterprise. There is no objectivity in it. Any saga is social construction. At university it should be pluralistic and critical, not glorify deeds. Teachers should be quick to point out fallacies of Eurocentrism in a global economy. But it is no vice to teach students that they own a rich common and connected European business heritage which is theirs to discover and pass on to others. In a Shakespearean way, the past is prologue: It sets the stage for the next act. Understanding what stage he is on does help an actor to find his role.

\section{NOTES ON NARRATIVES AND CREATIVE TEACHING}

Business history is the field of histories of management and organization, applied technology, work, consumption, social styles, stakeholder relations in society, and of course the biographical account of enterprises. Despite strong national currents in business history, IB's focus should be on the comparative and transnational. A key ingredient is the history of multinational enterprises (MNE). It would be wrong to only look at MNEs in Europe. Using intercontinental interaction and globalization as a prism or lens to look at European past experience is productive. Globalization is a vital and standard theme of IB curricula and textbooks, discussing competing ideas - for example, is globalization a recent force, an evolution since the dawn of human history, or a pendulum swinging back and forth (Peng \& Meyer, 2011, p. 17)? In a longer view, students can see that Europe has driven and profited by globalization, so perhaps they should not fear it.

Business history relies mainly on cases. "Applied" disciplines like to foster inductive learning from examples. A case is concrete and memorable. Stu- dents draw lessons more easily. What works in general management education works in business history. The challenge lies in selection when time plans allow only for a few hours. What period, what region? What industry? What message? One may feel pressed to build a representative sampler, but well-balanced comprehensiveness is illusory. A pragmatic approach is to test one's favorites and allow for pedagogical trial and error.

Later the author's own selections will be summarized without referencing all details; topic literature cited is in English and introductory. A suggestion for broader works is thus in order here: Jones' and Zeitlin's Oxford Handbook of Business History (2010) is an allrounder. In it, Kipping and Üsdiken (2008) relate business history and management science. Good shelf additions are Ferguson's Civilization: The West and the Rest (2011) and Ascent of Money (2008); The World that Trade Created by Pomeranz/Topik (2006), McCraw's Creating Modern Capitalism (1998), Cassis' Big Business: the European Experience in the 20th Century (1997), Berend's Economic History of 20th Europe (2006), and Broadberry's Cambridge Economic History of Modern Europe (2010). Wilkins (2008) reviews MNE literature. To counter the typical Anglo-American view that Europe's widespread family ownership of big business is a flawed idea, James' Family Capitalism (2006) is helpful. Recommended journals are Business History, Enterprise and Society, Business History Review, Itinerario, Enterprise and Society, Zeitschrift für Unternehmensgeschichte, Entreprises et Historie; among online media, The Exchange (exchange-bhc.blogspot. de), Bloomberg's Echoes: Dispatches from Economic History (bloomberg. com/view/echoes), and a syllabus collection, Guide to Business History Courses Worldwide of Harvard's Business History Initiative (hbs.edu/businesshistory). The European Business History Association, Business History Conference, and national groups offer insightful papers and many useful links.

History works on narrative, so ideally instructors are master storytellers. 
For once, PowerPoint is a real help for visualizing. Lectures can rely strongly on images, films and multimedia capsules, from YouTube to museum or educational websites. For example, Harvard's (2007) Historical Returns site on the South Sea Bubble has a decent video. Online cartoon films add a touch of fun, like Richard Condie's John Law and the Mississippi Bubble (1978) or Bob Godfrey‘s Great (1975) on Britain's daredevil entrepreneur Isambard Kingdom Brunel (the author has seen his students singing its tune "It Can't Be Done" on a subway). TV documentaries are sold on DVD; so are movie classics. For example, the author used scenes from A Dispatch from Reuters (1940) to dramatize high-risk investments in telegraph networks and electrifying impacts its use had on stock markets.

Lecturers should not be afraid to use a playful approach, even if that means, taking cues from museum pedagogy and history marketing, to wear wig and costume as a "living history" interpreter. Students love this (and put their in-class photos on social media while the lecture is still on). They can be assigned to work with artifacts, company documents, statistics, charts, newspapers, ads, posters, cartoons or satire sheets. Digitization has made many primary sources available online. Stovall (2010) demonstrates experiential learning tryouts, e.g. role-playing the Hawthorne Studies, planning a historic megaproject, or working an assembly line with Lego bricks kits. In the author's telegraph unit, T-mail crews strung a line across lecture halls, used simple telegraph kits, and competed with mobile phone text-messaging (aha moment: SMS can be beat by a 170-year-old technology). Classes may be blended with web quests, e-discussions, online and PC games.

Museum excursions are natural, but not every local craft gallery fits IB. Large technical museums may be a good choice. They are full of company stories. Take Berlin's: next to its planes, aviation floors colorfully portray airlines' and airports' beginnings and social sides of air travel. Museums of industry, work, post, or firm collections (e.g. BMW or Siemens Museums in
Munich), or seaport museums on shipping and commodities (sugar, coffee, cocoa, tea, fruit, grains, cotton, tobacco, metals, oil) can be visited for quizsheet treasure hunts, hands-on activities, or private seminars. Foreign study tours are great opportunities if taken off standard tourist tracks. Expert city walks in financial, commerce or industry quarters can be found with a local agency. Educational institutions often offer special packages. In London, the author's students learned a semester's worth at the Museum of Brands (marketing), the Bank of England (money), and in a seminar on sugar trade in the Docklands (sea trade). At the British Library, the curator encouraged awed students to flip through original 300-year-old ship logs and account ledgers of the East India Company.

\section{BIRTH OF THE MULTINATIONAL COMPANY}

The author's first selection unfolds as theatrical melodrama on screen. Drums roll, ocean winds whistle. Full with cargo, cannon ready, tall ships glide past exotic harbors. "The most powerful companies in history," booms a deep voice. "From trading, they gathered immense wealth. And they waged wars against each other. Can you create a company that will dominate all others?"

The colorful trailer for PC trade simulation East India Companies has a fierce tone. It fits the firms' combative tactics and nasty social record; they are not a convenient legacy for Europe. But they "shaped the modern multinational" as prototypes (Robins, 2006). They drove globalization and created big-organization careers with crosscultural versatility. Their top managers were "merchant kings" in an "age of heroic commerce" when "companies ruled the world" (Bown, 2009, p. 1). But as Bowen et al. (2011) point out, Europe's "monsoon traders" had to reconcile with Asia's local market powers and fine-tune diplomacy. Almost forgotten, they were rediscovered in the 1990s. Their histories "resonate with growing contemporary concerns over multinational businesses and the rapacious effects of globalization"; so the East India company "appears relevant again" (Blythe, 2011, p. 185). They lived by state power handed to them for public purpose, so they are a bit similar to today's state-backed firms coming out of emerging markets (Economist, 2011, p. 111).

In the age of mercantilism, Europe chartered some 70 companies with national trade monopolies. The "spice race" started the run for exotic goods, then adding saltpeter, indigo, tea, porcelain, silk, cotton, sugar, coffee, tobacco, opium. Fleets went first to the East Indies, then traded in all Asia, Afri$\mathrm{ca}$, and the Americas. Their trade outposts were called "factories," which over time evolved from purchasing agencies to production centers. In some lands, they forced colonial rule over the locals. In Europe, their imports profoundly changed consumer culture, habits and lifestyles.

Two firms stand out: Verenigde OostIndische Compagnie (VOC, 16021798) and the English East India Co. (EIC, 1600-1874). The VOC was formed when Dutch cities' rivaling merchant chambers united to form a cartel. Their board managed, together with regional governors, a huge empire. "Statistically, the VOC eclipsed all of its rivals in the Asian trade," says the Dutch National Archive: In its heyday, 30,000 people of many colors were employed in 50 locations worldwide. In 200 years of operation, it sent one million Europeans to work in Asia trade, more than the combined rest of Europe. 4,800 ships filled their cargo holds with 2.5 million tons of Asian goods (Boven, 2002, p. 14). It is a key lesson that for all its might, VOC went broke for poor cost control, loose leadership and bad strategy in changing markets. Unchecked graft let people joke, VOC stood for "Vergaan Onder Corruptie," perished by corruption (Reynders, 2002). Rival EIC lived longer, but its profitable monopoly was killed by home industrialists' rising lobby pushing for free trade (Keay, 1993, p. 451).

The VOC was the world's first jointstock company. Investors pooled risk by what the Dutch called "acties," pieces of the action. They formed a legal body state-privileged by limited 
liability. In Micklethwait's (2005) account The Company: A Short History of a Revolutionary Idea, this made the corporation the key unit of modern economies. The stock exchange was its child, too. The Amsterdam Beurs, origin of today's NYSE-Euronext, opened to serve VOC shareholders who could not sell stocks back to the firm. They had to sell on a secondary market. Traders then found they could use VOC shares as underlying assets for contracts: derivatives were born. The tricky trade of short-selling came next. London copied the Amsterdam model but grew faster: More firms traded, liquidity rose, and public debt was floated. The English utilized the securities market more effectively (Petram, 2011, p. 184). Had the VOC used its own exchange better, it may have survived longer; but it relied on "old methods of financing for too long" (Gaastra, 2003, p. 173).

\section{WHEN MARKETS BLOW BUBBLES}

In Wall Street: Money Never Sleeps (2010), evil speculator Gordon Gekko ("greed is good") has on his wall a painting, a Dutch tulip price index chart. It rises steeply, then drops to naught: the 1637 Tulipmania. "This is the greatest bubble story of all time," he tells a young trader. "People got wiped out. But who remembers?" Many do now, thanks to post-2008 debates. For "extraordinary passions it aroused" (Dash, 2001) and colossal fortunes lost, it has been cited over and over as a showcase of extreme mispricing due to easy credit and easy rules. It ended in crisis and state bailouts. It is a good yarn. But: myth-busting historians say Tulipmania is "an artifact" (Thompson E. , 2006, p. 99) or "based almost solely on propaganda" (Goldgar, 2007, p. 6). For some bubbles' hyped afterlife, it may be said "the bubble has itself been bubbled" (Hoppit, 2002, p. 141).

Tulipmania was not really an international affair. Most later bubbles were, so bubblenomics is fair game for an IB class. Bubbles are creatures of international business. Free cross-country capital flow aids them. "For the most part," says Kindleberger in his anatomy of Manias, Panics, and Crashes, "financial crises ricochet from one country to another." They "tend to be international and either affect a number of countries at the same time or alternatively spread from the centers where they originate to other countries" (2005, p. 124). So it was in 2008 , the 2000 Dotcom bubble, 1997 Asia meltdown, and 1987 Black Monday. Farther back, 1929 is popular to analogize to 2008.

Even more eerie is the familiar look of the 1873 panic ("Gründerkrach"). Viennas's bourse crashed first, then Berlin, then Italian, Belgian, Dutch, Swiss markets. New York went down; panic returned to Vienna. It had all begun with a collapse of Europe's construction boom, fired by young banks lending freely on loose collateral. In another arena, high-risk tools spiraled out of control: German investors in U.S. rail had built "a complex financial pyramid rested on a pinhead" (Nelson, 2008). Nervous over default, financiers pulled back. Interbank lending froze. Assets turned toxic. A credit crunch broke industrials, banks shut down, and a long depression followed in Europe and America.

1720 was the earliest European bubble year. Next to France and Britain, markets from Hamburg to Amsterdam, Milan to Lisbon were affected when the crisis hit. It began in London with the South Sea Company and the Mississippi Company in Paris. These firms sold investors, many foreign, on riches with emerging markets. On paper, they set to trade and colonize - but never did. Both firms involved state debt assets and public banks. Then Europe saw hundreds of "bubble companies" copying the cash-collecting model. The Dutch called them "windhandel" firms, selling the wind. It was a carnival of opportunistic start-ups without a business plan, bizarre foreign ventures and sure swindles. Long-term dividend payments were not what equity-buyers wanted. Their clever idea was "selling them on to greater fools. In a very short time, however, they were to discover that there were no greater fools in the market than themselves" (Chancellor, 1999, p. 72).

Students keen on international finance may later say in their careers, "this time it's different!," as in the title of Rogoff's and Reinhart's book (2011). They may think, "I know when to pull out." To make them wiser, they can reconstruct how infamous firms, like South Sea or Mississippi, attracted so many. Besides fraud and animal spirits, swings of judgment about uncertain future profits are at work: "In a bubble not everyone is irrational," notes Ferguson (2008, p. 122). It is hard to tell in a concrete situation if speculation is reasoned risk-taking or stupid gambling. Frehen et al. (2013) argue that 1720 bubbled because money was bet on real innovations: a shift from Asia to Atlantic trade, creative concepts to swap government debt for private stocks, and new models of maritime insurance. The market was not without fundamentals. But still, speculation made them matters of "extraordinary popular delusions and the madness of crowds" (Mackay, 1995).

\section{BUSINESS GOES ONLINE}

Today's students are digital natives, glued to their gadgets. They post, poke, tweet, skype, blog, stream, upand download constantly. They cannot conceive of IB careers without instant global data flow. One electrifying insight is that our digital network economy got off in the 1840s. Online pioneers created the world's first Internet in the 19th century; theirs was even more revolutionary than the Internet of the 20th, argues Standage (2009). The original e-mail was a t-mail, $t$ as in telegraph. It sparked the telecom and electric industries and enabled valueadding information services. One can trace a path "from dot-dash to dot. com" (Wheen, 2010). Student knowledge of the industrial age may be reconfigured: Around 1900, students usually guess the world's biggest MNE was a manufacturing giant. In reality, it was a European telegraph firm (Hugill, 1999, p. 32).

An "intimate relationship between the telegraph and commerce" developed (Wenzlhuemer, 2012, p. 88). This is especially true for IB: Where messages before telegraphy had traveled days, weeks or months, they were now relayed in minutes. From efficient shipping and railway logistics to mail-order 
catalogues, price data to feeding content to mass media, the wire was indispensable. It was not cheap, but firms were willing to pay premium rates. Constant updating kept firms competitive, and telegraphy "was like a drug to businessmen, who swiftly became addicted" (Standage, 2009, p. 166) like smartphone-obsessed managers today. Bankers and investors by the 1870 s equipped offices with a ticker constantly spitting out real-time stock quotes, a teleprinter. Its alphanumerical code lives on in "ticker symbols" for listed companies still scrolling over websites and TV screens.

Managers used the telegraph to lead and scale up ever-larger firms. It offered headquarters direct reach in vast territory. It widened the span of control. Coordinated companies could grow into really big business. One telegraphy-era tool every business students knows is the organization chart. First used in railroads, it not only set hierarchies but reporting and data flow (Rosenthal, 2013).

Bypassing middlemen, merchants and factories now could make online deals with distant suppliers or customers: "Suddenly the price of goods and the speed with which they could be delivered became more important than their geographic location" (Standage, 2009 , p. 165). Equity and commodity bourses used to be slow-paced. Many regional exchanges only served small areas. Telegraphy integrated fragmented markets, and had centralizing effects. Bourses with larger markets made better prices - if traders got current price information: "It is axiomatic that a market cannot be larger than the area in which communication is, effectively, instant," says Gordon (2000, p. 80). Across Europe, agencies for time-sensitive news sprang up like those of Charles Havas (Paris), Bernhard Wolff (Berlin), Guglielmo Stefani (Turin) and Paul Julius Reuter, a German in London. His firm, Reuters, now with 60,000 staff in $100+$ countries, promotes itself as "the world's leading source of intelligent information for businesses and professionals." In 2007, Reuters Group plc sold for $€ 13$ billion to Thomson Corp., overtaking rival Bloomberg (Thompson, 2007).
International demand for line infrastructure was huge. That was a chance for foreign specialists like the small Berlin equipment workshop, Telegraphen Bau-Anstalt von Siemens \& Halske. It grew fast as a state contractor for network systems, and as a cable maker. Public procurement can be tricky. Blamed for technical failures, Siemens fell out of favor with the Prussian state. Its home market destroyed, the firm survived by opening foreign subsidiaries. The czar let Siemens wire Russia from Finland to the Crimea. When it then finished the $11,000 \mathrm{~km}$ Indo-European Line to Calcutta in just two years, it was a sensation. Siemens secured projects in the Americas and Africa. It equipped China, Indonesia, and Japan before the century ended. It entered transatlantic cable business, too. It was a high-risk venture to lay "threads across the ocean" (Gordon, 2003), but by 1900 hundreds of thousands of kilometers of submarine cables connected Europe with all continents via seabed. Students may compare current and historic global cable maps: They realize that when using nonEuropean websites, they run data on a century-old network (just with better bandwidth, thanks to optical fibre). The telegraph business had made the world a smaller place.

\section{MEGAPROJECT: EUROPE AT SUEZ}

Energy firm GDF Suez is one of Europe's oldest MNEs. With 220,000 employees in 70 countries and as a Euronext CAC40 blue chip, it ranks 95th on Forbes' Global2000 list of "most powerful" firms; among electric utilities, it ranks second (DeCarlo, 2013). What is most curious is the name. GDF stands for the merged-in Gaz de France. But Suez? As in, Suez Canal? Yes. The firm, born 1859, built the waterway. The Compagnie universelle du canal maritime de Suez ran it until 1956 when Egyptian nationalists took it away. France and Britain staged a military invasion to retrieve the canal, but were halted by the UN. In Paris, the firm sat as "mere pawn in a wider political game" (Bonin, 2010, p. 474). Stranded as a canal company with no canal, it changed into a bank group. But in the 1990s, it morphed into an all-European utilities champion, "quite a business school case study for a Europeanization management model," (Bonin, 2005, p. 25). In a portrait discussing the firm's plans, the Financial Times ran a headline, "GDF Suez rekindles spirit of Lesseps" (Betts, 2010). How can a 21 st century student understand this 21 st century headline?

The FT observed, GDF Suez has been "steadily returning to its old Suez Canal roots" by going "back to its industrial origins," and pursuing grand plans in the Middle East (Betts, 2010). Company founder Ferdinand de Lesseps had lobbied the Ottoman Empire to fulfill Napoleon's dream: part the desert to shorten shipping from Asia to Europe by $6,000 \mathrm{~km}$. Since opening 1869 , the bulk of trade between Europe and Asia travels through it, i.e. 10-15 percent of global seaborne trade goods (Khankishiyeva, 2013). This likely includes most students' pants, shirts, shoes, pens and bags, smartphones, laptops, the gasoline in their car's tank, if not the (Asian made) car itself. In 2012, 16,600 ships with 755,000 tons of cargo passed, and paid $€ 5$ billion tolls (SCA, 2014). A fleet of EU warships protects this trade lifeline from pirates and terrorists south of Suez.

Lesseps' project was truly European. European management was key to all stages - winning legal concessions, filling a capital pool, finding contractors, operating the ten-year moving construction site. The firm's top managers and engineering crew had many passports. The project came to life on a common European belief in that it could be done. It successfully created attention in Europe. It was less good at finding pancontinental financing. Leading banks were unenthusiastic, so the firm went public to recruit middleclass investors. Its book-building road show went to a dozen nations. Securities sold well in France but flopped everywhere else, partly due to British sabotage. Britian feared for its supremacy at sea. Ironically, it later became the firm's major shareholder.

1.5 million Egyptians worked on the canal in a decade. Many were corvée laborers supplied by the Egyptian state. In a long scandal, the company was attacked as a slaveholder. Its mana- 
gers tried to defend the firms' practices in the European media, and prove human conditions. Yet diseases, heat, lack of water and care took their toll: 35,000 workers died (Wilson, 1939, p. 31). Clearly, this is a good case for teaching about a multinational firm's Corporate Social Responsibility (CSR).

Most of the $164 \mathrm{~km}$ were dug by hand, sand carried away by mules and camels. Only later did the firm find enough capital to bring in steampowered machines. Sometimes there were no workers, materials, or no contractors, or no legal authorizations, or no money to go on. Hence, Suez set the standard for cost overruns (and lying about it) in transport infrastructure, says megaprojects expert Bent Flyvbjerg: "Actual construction costs were 20 times higher than the earliest estimated costs and three times higher than the cost estimate for the year before construction began" (2002, p. 286). It took years before the Canal became profitable for the company, but finally the firm thrived.

The host country hardly profited at all, which Europeans ignored until the sun set on colonialism. They also neglected economic development of the canal corridor. For 144 years, its banks have been empty. Ports and canal communities are poor, jobless, and hotbeds of violent rebellion. In a new megaproject, Egypt plans to make the area a world hub for logistics and industry (Werr, 2012).

\section{SHARING THE SKIES}

Civil aviation is the most international of international businesses. But airlines have never been "just another industry" (Rhoades, 2008, p. 3). Relative to their size, they get overproportional attention but usually underperform. They tend to be undercapitalized, suffer high fixed operating costs, and yield ridiculously low profit margins. When Europe's airlines took off in the 1920s, the situation was the same. Except that flying was still an adventure, and managers were still inventing the airline.

European airlines flew on two wings. First, they were from the start international. It made no sense to fly only domestic. Countries were too small. Even large nations could be traveled well by ground transport. Some airlines were what IB theory 70 years later described as "born global," a firm type which internationalizes instantly "by design and not by emergence" (Tanev, 2013, p. 5). Second, the state was ever-present. It regulated the industry heavily. It offered lucrative air mail contracts which "subsidized the passengers and made it worthwhile to bother with them" (Hudson \& Pettifer, 1979 , p. 51). It paid other subsidies, or even became owner. Most airlines started on private initiative but came fast under state influence. Privileged firms became flag carriers of the nation, evolving into "government birds" (Staniland, 2003). Britain, France, Belgium, the Netherlands, Italy, Spain, and Portugal financed a national air service to connect homeland and colonies. It was a matter of national prestige, "almost unthinkable" not to have one (Dierikx, 2008, p. 13).

Deutsche Luft Hansa had no such task in the 1920s. Germany had lost its colonies and was restricted in aviation development. Still, DLH received generous subsidies. A visible airline was important politically. Germany was forbidden to have an air force, and national reputation was in need of repair. DLH was to promote exports, expand commercial relations, and be a symbol for Germany's technical and economic leadership (Fritzsche, 1992, p. 178). DLH spread its wings over Europe and concentrated on linking major cities; by the late 1920s, it flew more passengers and kilometers than all neighbor airlines combined. It became "Europe's first 'European' airline" (Lyth, 2011, p. 262). There were global ambitions, too. DLH was able to compete hard in remote places (Crouch, 2003, p. 212). DLH had subsidiaries in Brazil (Condor) and Spain (Iberia). Forerunner Junkers had already connected Turkey, Persia, and South America, which was a hot spot for Germans interests. In a highly political deal with the revolutionary Soviet Union, DLH co-owned German-Russian airline Deruluft, and for China mail, it created the Eurasia Aviation Corp.

To fly cross-border, foreign airlines had to rely on bilateral state agreements. After World War I, air law was strict. States insisted on full sovereignty over their airspace, unwilling to apply to the sky maritime law's "freedom of the seas" principle that oceans are open to all trade. Only in 1944 did a UN conference in Chicago declare "freedoms of the air". With many wrenches thrown in the works, "it was almost miraculous that the 1920s and 1930s saw the development of an extensive international network of air services," notes Dierikx; often, political obstacles "at the negotiating table were even bigger than the actual problems to be overcome en route" (2008, p. 15). Airlines, fearing dog-eat-fog competition, tried to iron out matters among themselves. In 1919, managers of six young airlines (British, Danish, Dutch, German, Norwegian, and Swedish) founded the International Air Traffic Association (IATA) - which is still key in today's global air transport. Its members began to standardize ticketing, booking, safety and technical rules, passenger rights, liability and insurance, and to synchronize schedules. Most European airlines became IATA members fast. By the 1930s this European idea drew in firms from Africa, Asia, and the Americas. It became the "parliament of the world's airlines." Its relaunch after 1945 led to state-ratified price-fixing which, for some, made IATA "one of the most hated cartels in the world" (Sampson, 1985, p. 10). The cartel "suited the Europeans" because it protected profits of weak airlines (Heppenheimer, 1995, p. 117).

\section{CONCLUSIONS}

The five compact cases presented here are suggestions meant to engage the reader in thinking about scenarios for class, based on examples from the author's teaching in 2010-12. Detailed tips for didactics, methods or media have not been given here, nor has student feedback been discussed For that, the author refers back to section II. Rather, the author's intention was to introduce to the motivated non-historian reader what kind of themes and topics may be used in an IB class. Historic cases should be interesting to the student who is not per se interested in history. If told that "history matters!", he may 
not be all that all willing to make an extra effort to find out all by himself how history matters. This is for the professor to prove. To link yesterday's legacy of European business with today's critical questions is, of course, key to making this kind of teaching relevant.

\section{LITERATURE}

Banús, E. (2007). Educate European identity? Journal of Social Science Education, 6(1), S. 57-67.

Bedeian, A. G. (2004, March). The gift of professional maturity. Academy of Management Learning \& Education, 3(1), pp. 92-98.

Berend, I. T. (2006). An economic history of twentiethcentury Europe: economic regimes from laissez-faire to globalization. Cambridge: Cambrige Univ. Press.

Betts, P. (2010, March 4). GDF Suez rekindles spirit of Lesseps. Retrieved August 3, 2013, from Financial Times: http://www.ft.com/intl/cms/s/0/92b4983c-27c711df-863d-00144feabdc0.html\#axzz2etV6ZxCe

Blythe, R. J. (2011). Smoke, and flame, and thunder: The company, its demise and its legacies, . 1830-70. In H. V. Bowen, J. McAleer, \& R. J. Blyth, Monsoon traders. The maritime world of the East India Company (pp. 158185). London: Scala.

Bonin, H. (2005). Suez: The endeavour to evolve from a French flagship in utilities to a European corporation (1982-2006). Retrieved August 3, 2013, from HubertBonin.com: http://boninhub.free.fr/files/documents/ BONIN\%20SUEZ\%20SCHROTER\%2022\%20APRIL.doc Bonin, H. (2010). History of the Suez Canal Company 1858-1960: between controversy and utility. Geneva: Droz.

Boven, M. W. (2002). Nationaal Archief TANAP memory of the world register nomination. Retrieved from Unesco: http://portal.unesco.org/ci/en/files/2 2635/11546101681netherlands_voc_archives.doc/ netherlands\%2Bvoc\%2Barchives.doc

Bowen, H. V., McAleer, J., \& Blyth, R. J. (2011). Monsoon traders. The maritime world of the East India Company. London: Scala.

Bown, S. R. (2009). Merchant kings. When companies ruled the world, 1600-1900. London: Conway. Broadberry, S. (2010). The Cambridge economic history of modern Europe, vol. 2: 1870 to the present. Cambrigde: Cambridge Univ. Press.

Bucheli, M. (2012). Integrating business history in a friendly environment where no previous tradition existed. Teaching business history: insights and debates [ed. G. Jones \& W. Friedman] (pp. 16-18). Cambridge, Mass.: Harvard Business School.

Cassis, Y. (1997). Big business: the European experience in the 20th Century. Oxford: Oxford Univ. Press.

Chancellor, E. (1999). Devil take the hindmost: a history of financial speculation. New York: Penguin.

Crouch, T. D. (2003). Wings. A history of aviation from kites to the space age. New York / London: W.W. Norton.

Dash, M. (2001). Tulipomania. The story of the world's most coveted flower \& the extraordinary passions it aroused. New York: Broadway Books.

DeCarlo, S. (2013, April 17). The world's biggest companies. Retrieved August 3, 2013, from Forbes Global 2000: http://www.forbes.com/global2000/

Dierikx, M. (2008). Clipping the clouds. How air trave changed the world. Westport: Praeger.
Banús, E. (2007). Educate European identity? Journal of Social Science Education, 6(1), S. 57-67.

Bedeian, A. G. (2004, March). The gift of professional maturity. Academy of Management Learning \& Education, 3(1), pp. 92-98.

Berend, I. T. (2006). An economic history of twentiethcentury Europe: economic regimes from laissez-faire to globalization. Cambridge: Cambridge Univ. Press.

Betts, P. (2010, March 4). GDF Suez rekindles spirit of Lesseps. Retrieved August 3, 2013, from Financial Times: http://www.ft.com/intl/cms/s/0/92b4983c-27c7 11df-863d-00144feabdc0.html\#axzz2etV6ZxCe

Blythe, R. J. (2011). Smoke, and flame, and thunder: Th company, its demise and its legacies, . 1830-70. In H. V. Bowen, J. McAleer, \& R. J. Blyth, Monsoon traders. The maritime world of the East India Company (pp. 158185). London: Scala.

Bonin, H. (2005). Suez: The endeavour to evolve from a French flagship in utilities to a European corporation (1982-2006). Retrieved August 3, 2013, from HubertBonin.com: http://boninhub.free.fr/files/documents/ BONIN\%20SUEZ\%20SCHROTER\%2022\%20APRIL.doc Bonin, H. (2010). History of the Suez Canal Company 1858-1960: between controversy and utility. Geneva: Droz.

Boven, M. W. (2002). Nationaal Archief TANAP memory of the world register nomination. Retrieved from Unesco: http://portal.unesco.org/ci/en/files/2 2635/11546101681netherlands_voc archives.doc/ netherlands\%2Bvoc\%2Barchives.doc

Bowen, H. V., McAleer, J., \& Blyth, R. J. (2011). Monsoon traders. The maritime world of the East India Company. London: Scala.

Bown, S. R. (2009). Merchant kings. When companies ruled the world, 1600-1900. London: Conway.

Broadberry, S. (2010). The Cambridge economic history of modern Europe, vol. 2: 1870 to the present Cambridge: Cambridge Univ. Press.

Bucheli, M. (2012). Integrating business history in a friendly environment where no previous tradition existed. Teaching business history: insights and debate [ed. G. Jones \& W. Friedman] (pp. 16-18). Cambridge, Mass.: Harvard Business School.

Cassis, Y. (1997). Big business: the European experience in the 20th Century. Oxford: Oxford Univ. Press.

Chancellor, E. (1999). Devil take the hindmost: a history of financial speculation. New York: Penguin.

Crouch, T. D. (2003). Wings. A history of aviation from kites to the space age. New York / London: W.W. Norton.

Dash, M. (2001). Tulipomania. The story of the world's most coveted flower \& the extraordinary passions it aroused. New York: Broadway Books.

DeCarlo, S. (2013, April 17). The world's biggest companies. Retrieved August 3, 2013, from Forbes Global 2000: http://www.forbes.com/global2000/

Dierikx, M. (2008). Clipping the clouds. How air travel changed the world. Westport: Praeger.

Economist. (2011, December 17). The Company that ruled the waves. Economist, pp. 111-113.

Ferguson, N. (2008). The ascent of money: A financial history of the world. London: Penguin.

Ferguson, N. (2011). Civilization: the West and the rest. London: Penguin.

Flyvbjerg, B., Holm, M. S., \& Buhl, S. (2002). Underestimating costs in public works projects: error or lie? Journal of the American Planning Association, 68(3), pp. 279-295.

Frehen, R. G., Goetzmann, W. N., \& Rouwenhorst, K. G.
(2013, June). New evidence on the first financial bubble. Journal of Financial Economics, 108(3), pp. 585-607.

Fritzsche, P. (1992). A nation of fliers. German aviation and the popular imagination. Cambridge, Mass.: Harvard Univ. Press.

Gaastra, F. S. (2003). The Dutch East India Company: expansion and decline. Zutphen: Walburg Pers.

Goldgar, A. (2007). Tulipmania: money, honor, and knowledge in the Dutch Golden Age. Chicago: Univ. of Chicago Press.

Gordon, J. S. (2000). The great game: the emergence of Wall Street as a world power, 1653-2000. New York: Touchstone.

Gordon, J. S. (2003). A thread across the ocean: the heroic story of the transatlantic cable. New York: Harper Perennial.

Harvard Business School. (2007). Financial bubbles. Retrieved from Historical returns: http://www.library. hbs.edu/hc/historicalreturns/fb/

Heppenheimer, T. A. (1995). Turbulent skies. The history of commercial aviation. New York: Wiley.

Hochschule Osnabrück. (2011, April 12). Hochschule Osnabrück reagiert auf Finanzkrise [press release]. Retrieved August 1, 2013, from Hochschule Osnabrück: http://www.hs-osnabrueck.de/722+M5c7e79a0f6e. htm

Hoppit, J. (2002). The myths of the South Sea Bubble. Transactions of the Royal Historical Society, 12(1), pp. 141-165.

Hudson, K., \& Pettifer, I. (1979). Diamonds in the sky: a social history of air travel. London: Bodley Head / BBC. Hugill, P. J. (1999). Global communications since 1844 geopolitics and technology. Baltimore: Johns Hopkins Univ. Press.

James, H. (2006). Family capitalism: Wendels, Haniels, Falcks, and the continental European model. Cambridge, Mass.: Harvard Univ. Press.

Jones, G., \& Zeitlin, J. (2010). The Oxford handbook of business history. Oxford: Oxford Univ. Press.

Keay, J. (1993). The honourable company. A history of the English East India Company. London: HarperCollins. Khankishiyeva, E. (2013, August 26). Egypt's economy: light at end of tunnel. Retrieved September 6, 2013, from Trend News Agency: http://en.trend.az/capital/ analytical/2182542.html

Kindleberger, C. (2005). Manias, panics, and crashes: a history of financial crises [5th ed.]. Hoboken, NJ: John Wiley \& Sons.

Kipping, M., \& Üsdiken, B. (2008). Business history and management studies. In G. Jones, \& J. Zeitlin, The Oxford handbook of business history (pp. 96-119). Oxford: Oxford Univ. Press.

Lyth, P. (2011). Deutsche Lufthansa and the German state, 1926-1941. In T. Gourvish, Business and politics in Europe, 1900 - 1970 (pp. 246-268). Cambridge: Cambridge Univ. Press.

Mackay, C. (1995). Extraordinary popular delusions and the madness of crowds. Ware: Wordsworth.

McCraw, T. K. (1998). Creating modern capitalism: how entrepreneurs, companies, and countries triumphed in three industrial revolutions. Cambridge, Mass.: Harvard Univ. Press.

Micklethwait, J., \& Woodrigde, A. (2005). The company: A short history of a revolutionary idea. New York: Modern Library.

Mittelstaedt, E., Lutz, R., \& Wiepcke, C. (2013). The financial crisis - an ideal teaching moment. Journal of Social Science Education, 12, pp. 11-20.

Nelson, S. R. (2008, October 17). The real Great 
Depression. Retrieved August 25, 2013, from Chronicle of Higher Education: http://srnels.people.wm.edu/ articles/realGrtDepr.html

Peng, M., \& Meyer, K. (2011). International business. London: Cengage Learning EMEA.

Petram, L. O. (2011). The world's first stock exchange: how the Amsterdam market for Dutch East India Company shares became a modern securities market, 602-1700 [Dissertation]. Retrieved from Amsterdam University: http://dare.uva.nl/document/201694

Pomeranz, K., \& Topik, S. (2006). The world that trade reated. Society, culture, and the world economy [2d ed.]. Armonk, NY / London: M. E. Sharpe.

Reinhart, C. M., \& Rogoff, K. S. (2011). This time is different: eight centuries of financial folly. Princeton: Princeton Univ. Press.

Reynders, P. (2002). Why did the largest corporation in the world go broke? An economic review. Retrieved from Project Gutenberg Australia: http://gutenberg.net. au/VOC.html

Rhoades, D. L. (2008). Evolution of international aviation: Phoenix rising. Farnham: Ashgate.

Robins, N. (2006). The corporation that changed the world: how the East India Company shaped the modern multinational. London: Pluto Press.

Rosenthal, C. (2013, March). Big data in the age of the telegraph. Retrieved August 3, 2013, from McKinsey Quarterly: http://www.mckinsey.com/insights/organization/big_data_in_the_age_of_the_telegraph

Sampson, A. (1985). Empires of the sky. The politics, contests and cartels of world airlines. Hodder, Stoughton: Coronet.

SCA. (2014). Suez Canal statistics. Retrieved May 15 2014, from Suez Canal Authority: http://www.suezcanal.gov.eg/TRstat.aspx?reportld $=4$

Standage, T. (2009). The Victorian Internet: the remarkable story of the telegraph and the 19th century's on-line pioneers. New York: Bloomsbury.

Staniland, M. (2003). Government birds: air transport and the state in Western Europe. Lanham, Md.: Rowman \& Littlefield.

Stovall, S. A. (2010). Recreating the arsenal of Venice using experiential activities to teach the history of management. Journal of Management Education, 34(3), S. $458-473$.

Tanev, S. (2013, March). Global from the start: the characteristics of born-global firms in the technology sector. Technology Innovation Management Review, 8(3), pp. 5-8.

Thompson, E. (2006). The tulipmania: fact or artifact? Public Choice, 130, pp. 99-114.

Thompson, M. (2007, May 15). Thomson,

Reuters to forge global info leader. Retrieved August 10, 2013, from Reuters.com: http://www. reuters.com/article/2007/05/15/us-reuters-thomsonidUSL1553044220070515

Wenzlhuemer, R. (2012). Connecting the nineteenthcentury world: the telegraph and globalization. Cambridge: Cambridge Univ. Press.

Werr, P. (2012, October 10). Egypt sees revenue in Suez Canal corridor project. Retrieved August 3, 2013, from Reuters.com: http://www.reuters.com/article/2012/10/10/us-egypt-canal-idUSBRE8990Y920121010 Wheen, A. (2010). Dot-dash to dot.com: How modern telecommunications evolved from the telegraph to the Internet. New York: Springer.

Wilkins, M. (2008). The history of the multinational enterprise. In A. M. Rugman, The Oxford handbook of international business (S. 3-38). Oxford: Oxford Univ. Press.
Wilson, A. T. (1939). The Suez Canal. Its past, present, and future [2d ed.]. Oxford: Oxford Univ. Press.

\section{AUTHOR}

\section{Prof. Dr. Marco Althaus}

Social Sciences

Department of Business, Computing and Law Technical University of Applied Sciences Wildau

$\mathrm{T}+493375$ 508-34

marco.althaus@th-wildau.de 